\title{
Extending of the Legal Order During Pandemic: The Russian Perspective*
}

\author{
Mark Belov \\ Research Assistant, Centre for Fundamental Sociology; \\ Undergraduate Student, School of Law, HSE University \\ Address: Myasnitskaya str., 20, Moscow, Russian Federation 101000 \\ E-mail: markusabelov@gmail.com
}

\begin{abstract}
The unprecedented measures of quarantine regulation have led philosophers and lawyers around the world to speak of the fragility of democratic freedoms and the return of the state of emergency as a political reality described in the writings of 2oth century theorists. However, the imposed restrictions are considered in the works either in relation to the legal mechanism of their imposition, or through the prism of political philosophy. In addition, the Russian experience has not been sufficiently highlighted in the publications. This article attempts to synthesize legal analysis with political-legal philosophy in order to show that the extension of the legal order is always embedded in its logic. The first part of the article shows how what has been mentioned at the level of philosophical reflection and in relation to foreign legal orders that have been implemented in Russia, using the example of substantive legal practice. The second half of the text draws attention to the logic of protest which coincides with the logic of both the police and the state. Since the rights to which the protesters draw attention to have their source precisely in the existing legal order, both the actions of the law-enforcement authorities and the actions of the protesters are aimed at protecting it. The conclusion is that the danger of this situation is that the normative system could potentially replace social reality in the future.
\end{abstract}

Keywords: state of emergency, violence, law, legal-order, Walter Benjamin, pandemic

\section{Foreword}

As many have already noticed, the world after COVID-19 will not be the same. Not only have we found ourselves in a fundamentally new ontological reality in which we are beginning to account for an increasing number of non-human actors, but our socio-legal and political reality has also undergone significant changes. The unprecedented measures of quarantine regulation have generated intense debate both among jurists on the mechanism of the implementation of these measures and their relationship to constitutional rights, as well as political theorists and philosophers.

Nevertheless, it is difficult to talk about the state's response to COVID without going to extremes, as some public intellectuals have done. Critics risk being branded as pandemic-denialists, and advocates of explicit measures become targets of accusations of etatism. Neither of these two positions seem right, and if we allow the use of psycho-

* The results of the project "Ethics of Solidarity and the Biopolitics of Quarantine: Theoretical Problems of the Cultural and Political Transformations during Pandemic", carried out within the framework of the Basic Research Program at the National Research University Higher School of Economics (HSE University) in 2021, are presented in this work. 
analytic terms, they are both merely symptomatic manifestations of a structural problem that needs to be symbolized. I hope that the presentation of my view of the situation can avoid these two extremes.

To do this, we must first consider the triggers that caused this reaction, namely, the state's anti-COVID measures themselves. At this stage, there is no lack of conceptual grounding. There have been publications in which entire sections have been devoted to the socio-legal and legal dimension (Gephart, 2020). Meanwhile, the Russian experience has not yet been sufficiently highlighted precisely in terms of the interaction between political theory and law. There are either legal articles on the legal analysis of the imposed restrictions (Khramova, 2020; Varlamova, 2020), or sociological and philosophical works that look at the legal aspect from the perspective of the philosophy of law (Filippov, 2020). Clearly, this is due to disciplinary boundaries which are unavoidable. However, the conceptualization of a substantive legal practice, that is, the text of legislation and law enforcement, could squeeze the hegemony of lawyers inherent in the legal field.

The text of the law is an important element on the way to achieving this goal. The open texture of legal language that allows law to be interpreted when there is uncertainty at the borderline (Hart, 1994: 128) is also able to predetermine social reality. In a situation of uncertainty, the abstract wording and lack of understanding of the timing of the end of a disaster gives the law the power to decide when the necessary grounds for canceling the restrictions are in place, regardless of more-or-less objective facts. The legislator becomes a katechon to prevent the disruption of order, which is ensured by both the introduction of temporal measures and the tightening of the underlying legislation.

On the grounds of an analysis of the text of the constitutional court decision which legitimized and legalized the unconstitutional provision of the Governor of the Moscow region decree and the legislative innovations in the field of criminal law, I hope to show that violent police actions in clearing public spaces of mass crowds is a direct extension of the internal logic of the law. ${ }^{1}$ Here, however, a distinction must be made between Russian and European practices. Until recently, Russia has not faced demonstrations against the introduction of QR, but after the decision to tighten measures in the field of COVID-19 and the introduction of bans on visiting public places without $\mathrm{QR}$, we can observe protests with European-like slogans and even the disruption of administrative buildings' work (Nasulina, 2021; Novaya gazeta, 2021). These protests, both in Europe and Russia, are directly linked to the structure of the established legal order, as they aim to protect what the protesters consider to be fundamental rights. There seems to be a legal conflict in this case. However, there is no "conflict" as both sides are starting from a shared legal order, and are directing their actions towards preserving it. Of course, Russian protests have not reached the same level as in Europe, but a particular analysis of Russian legal practices that have led to events similar to those in Europe will reveal what these phenomena have in common in different parts of the world.

In the first part of the article I show, using the example of substantive legal practice, how what has already been mentioned at the level of philosophical reflection (Agamben,

1. It is the lex, not the ius, the essence of which I will not venture to identify in this text. 
2020) and in relation to foreign legal orders (Cormacain, Bar-Siman-Tov, 2020; Platon, 2020) has been implemented in Russia, namely, the implementation of a de facto state of emergency without its formal introduction and its consequences for both the political and legal spheres. In the second half of the text, I draw attention to the logic of protest which coincides with the logic of the police and the state. Since the rights to which the protesters draw attention have their source precisely in the existing legal order, I conclude that both the actions of the law enforcement authorities and the actions of the protesters are aimed at protecting it. The only difference is that the state is engaged in law-extending as well as law-preserving, which prevents it from recognizing the protesters as an ally.

\section{Russian Case-Law}

Before examining the normative component at the national level, it is worth looking at publications and statements from the international community. At the outset of the coronavirus outbreak, UN experts, recognizing the gravity of the crisis, pointed out that states should not abuse the restrictions imposed by using them to target certain groups of citizens, including human rights defenders (UN Experts, 2020). In further examining state reactions to the spread of COVID-19, it has been noted that the European Court will be called upon to recognize states' discretion in combating the coronavirus (Tzevelekos, 2020). Concerns can be seen that the measures introduced have led to various humanrights violations. In Russia, the right to a fair trial has been restricted, which, for example, is expressed in violation of the principle of publicity when conducting court sessions via videoconference. Courts have stopped allowing spectators and journalists, and recordings of video broadcasts are not made available to the public (Startceva, 2020). It should be mentioned that the European Convention on Human Rights allows for derogation in the event of war or other public emergency threatening the life of the nation. Each member state must inform the Secretary General of the Council of Europe when such measures are introduced.

The Russian Federation has not been known to introduce a state of emergency, but has used a regime of heightened readiness when an emergency situation threatens it. Although one of the conditions for the introduction of an emergency regime is the number of deaths over 50 people, the emergency regime was not introduced. As some observers have noted, there is no substantive difference between the emergency preparedness and emergency regimes:

Thus, Article 4.1(10) of the Federal Law on Protection against Emergencies sets out the measures which the authorities may apply in conditions of an emergency without distinguishing between the two regimes. Paragraph 28 of the Provisions on the Unified State System for the Prevention and Elimination of Emergency Situations specifies the measures to be applied under the high alert regime and the emergency regime in different subparagraphs " $b$ " and "c", but is abstract and does not allow for a meaningful distinction between the two regimes. (Merkulenko, 2021: 92) 
It also emphasizes the vagueness of the formulation of the objectives pursued by the restrictions (Khramova, 2020: 44). This leads to the inconsistency of the measures introduced with the principle of proportionality, according to which emergency measures should be dictated by the needs of the situation (Sajó, Uitz, 2017: 429).

It should be noted that the emergency regime and the state of emergency are two different regimes which, however, have no substantive difference other than the mechanism by which they are introduced. It is pointed out "that a regime of emergency (and hence a regime of high alert) may substitute for a state of emergency where it may be advantageous to the executive power in order to avoid the complicated procedure of an appeal to the Federation Council by the President of the Russian Federation" (Merkulenko, 2021: 95). The establishment of a formal state of emergency regime is supported by the limitation of such a provision to a certain period, which is a guarantee that exceptional powers will not be retained once the emergency has passed. Furthermore, the formal declaration of a state of emergency contributes to an awareness of the gravity of the situation and mobilizes society to overcome it (Varlamova, 2020: 21). If a state of high alert is considered in the logic of the law, it is one that responds to an extraordinary situation requiring special measures, but which is not serious enough to constitute a state of emergency (Khramova, 2020: 40).

Like the terrorist threat, COVID-19 threatens the good of the entire population and, therefore, the counter-terrorist state is quite comparable to the counter-COVID state, which also operates as a preventive state, where the state acts 'as preventer of crime and disorder generally' (Sajó, Uitz, 2017: 440). As Sajó and Uitz write: "After all, government is about public safety and security and in many welfare states, especially in Europe, public opinion expects government to guarantee social security on a preventive basis" (Ibid.). Laws enacted preventively or after the fact give the illusion of collective control, which is mostly absent (Roach, 2004: 185). Nonetheless, these preventive, life-preserving actions are triggered by extraordinary situations that end up turning the "social reality — law" pair upside-down, where the latter acquires the capacity to determine the former.

Schmitt, in his work "Legality and Legitimacy", distinguished three types of states: the parliamentary legislative state, the jurisdiction state, and the administrative state. Despite the proposed classification, the German thinker writes that each type of state has elements of the others, but it is always possible to identify the centre of gravity (Schmitt, 2004a: 3-6). While it would seem that the parliamentary legislative state has prevailed in the modern world, the events of September 11 (following which the doctrine of the preventive state was developed) rather brought all three types together in a common fiction. In the normal course of life, the parliamentary legislative state functions on the people's belief in the coincidence of right and law, but in times of nationwide threat, the legislative state transforms itself into an administrative state and starts to act on the basis of reality and the concrete situation $(6,21)$.

A clear example of this was the single judgment by The Constitutional Court of the Russian Federation of 25 December 2020, titled N 49-P, concerning measures to counter the spread of a new coronavirus infection. The Constitutional Court pointed out the legal- 
ity of restrictions on the movement of citizens imposed by the Governor of the Moscow region. ${ }^{2}$ The problem was that these measures were introduced on March 29, 2020, but it was not until April 1, 2020, that the authorities of the federal subjects were empowered to establish rules of conduct mandatory for citizens and organizations when introducing a regime of high alert or an emergency situation. That is, the rule was unconstitutional for three days (Merkulenko, 2021: 100). Thus, the imposition of restrictions was dictated not by a higher order by which the norm could be conditioned (Kelsen, 2008: 84), but by an objective necessity (Schmitt, 2004a: 8-9).

The Constitutional Court of the Russian Federation stated that "In the current extraordinary situation, the Governor of the Moscow Region, as the highest official of state power of the subject of the Russian Federation (this applies to most regions), in fact, implemented an operative (anticipatory) legal regulation, subsequently (after a short period) legitimised by legal acts of the federal level, which in itself cannot be regarded as contradicting the provisions of the Constitution of the Russian Federation". Since the modern state is not a pure administrative state, it has had to turn to the jurisdiction state in order to legitimize and legalize these measures in the eyes of the public. The boundaries of the legal order are extended in a situation where there is a lack of understanding of what is going on, and by introducing norms in response to dangerous events in order to further prevent them. However, the concepts of "public safety" and "necessary measures" can only be applied in a specific situation where the application of these concepts is crucial (Schmitt, 2004a: 32).

Such events illustrate a situation of concrete application of the law where a lower public authority in the hierarchy imposes a higher rule in defiance of a higher authority (55). In its ruling, the Constitutional Court explicitly states that the action of restricting movement is not unconstitutional because it is a reaction to an extraordinary situation. Having manifested itself for the first time, this situation requires a legal response, triggering the temporary legal regulation measures outlined above. However, the unpredictability of life forces the legal system to use a language that is open to evolutionary interpretation, to use the language of the European Court of Human Rights (Tyrer v. United Kingdom, no. 5856/72, ECHR 1978), that is to say, as interpreted in the light of present-day conditions. This inner dialectic of the law, where formality and clarity collide with openness and abstractness, is relieved by the release of the ability to define future reality normatively in a situation of emergency.

The very possibility of an unclear situation is constructed by the legislator through the abstract wording of restrictions and executive action in an extraordinary situation. Benjamin wrote that the ability to express abstractions is a result of the sinfulness of man. The Tree of Knowledge in the Garden of Eden did not provide information about good and evil, but symbolized judgment on the questioner (Benjamin, 1996a: 72). Legal language, insofar as Justicia speaks in it, is meant to express such abstractions as good, evil, and justice as the highest abstraction. Since we do not know what it will take to preserve

2. The same restrictions were invented by the Mayor of Moscow Decree No. 12-UM of 5 March 2020. 
safety, we will not create a concrete and exhaustive list of extraordinary limitations. This, it seems, is the dialectic of the concrete situation and the abstract law which resolves the crisis point of expanding legal order. A situation of ambiguity in this way is always potential and threatening; to overcome it, the substantive law is changed in a way that it could not have been changed in the normal course of life.

The absence of a formalized state of emergency can encourage the continuation of some measures through their incorporation into main legislation and tacit acceptance (Varlamova, 2020: 25). This, along with the impossibility of defining when the pandemic will end, is what is most dangerous. Provisions in the Russian Federation's criminal legislation were introduced to impose liability for violations of health and epidemiological regulations or for disseminating false information about the virus and its control. Such measures have been the subject of concern from international law scholars who point to their repressive potential (Seyhan, 2020). It has been noted that they are only indirectly related to the protection of public health and open to abuse (Khramova, 2020: 48). These rules are no longer extraordinary, but are aimed at empowering the legal order. Such a condition outweighs the risks associated with an officially declared state of emergency (Greene, 2020: 5). Although extraordinary circumstances were a condition for the adoption of these rules, in the future, it will be possible to determine whether the situation is favorable or not through these provisions, rather than objective facts.

The consideration of how the legal order is extended at the level of the legislative text allows us to move to the level of the analysis of practices which, on the one hand, put the prescriptions of the law, namely police and administrative practices, into social reality. On the other hand, there are practices that prevent this, i.e., the actions of protesters against the imposed restrictions. This will allow to distinguish between the law-preserving and law-extending violence of the state and the purely law-preserving violence of protesters.

\section{Law-Making of the Pandemic Period}

Walter Benjamin saw a peace agreement which established a new law as a result of military violence (1996b: 240). Today, when many scholars talk about the blurring of boundaries between a state of war and peace due to the emergence of new military technologies (Gusterson, 2016: 147), it is impossible to trace at what point a different law order is established. This logic may be extended to internal state borders. The global character of the threat allows us to speak of a "COVID war" both on the level of mass media (Kostyuchenko, Kozyrev, 202O; Interlandi, 2021) and in the context of legislative measures (UmnovaKonyukhova, Kostyleva, 2021: 110) for population protection. Of course, this war aims to destroy the enemy and does not imply any peace agreement. Although such a metaphor is justly criticized (Gauchet, 2020; Panzeri, Di Paola, Domaneschi, 2021), we accept it insofar as it reflects the impossibility of defining the boundaries of normal and extraordinary life in today's situation. However, in this state of volatility, unpredictability, and uncertainty, the law-making reveals itself in a different way. 
The German philosopher distinguished between divine and mythical violence. The latter, in turn, was divided into law-making and law-preserving violence. While the former defines the objectives of a legal character for itself, the latter is limited in this possibility (Benjamin, 1996b: 242-243). The state authority in the activity of which this distinction rubbed off was, for Benjamin, the police. It extends the boundaries of the legal order for security reasons when there is a lack of clarity (Ibid.). It is because the police extend the boundaries of the order but do not create a new one; in the gap between creating and maintaining order, I distinguish the law-extending violence. This is most vividly illustrated in law enforcement activities. From police batons to electroshocks and with each new mass gathering of citizens, the police asserted a new practice of maintaining order by their actions in a situation where they were fighting the spread of a new coronavirus infection. The remedy becomes the norm after it has been tried for the first time. Such actions are justified not only by the internal logic of the police force, but also by the state of emergency situation. Of course, the emergency situation does not permit the use of violence, but the actions of the protesters are seen as an encroachment on the welfare of the rest of the population. Protesters are thus excluded from political unity and designated as enemies in this war.

Agamben asserted that the camp as a space of the inability to decide where is reality and where is law, where is the norm and where is its application, and where is the exception and where is the rule, is the matrix of current politics today (1998: 173-174). In the camp, people do not understand the space they are in because they do not know the limits of their actions or those of the authorities and their limitations. A state of emergency in turn places the individual in front of the official fact of the restriction of freedom, allowing the subject to become aware of the reality of concentration. The state of emergency removes the subject from the sphere of legal certainty, but in doing so, it indicates that this certainty has never existed. With such an exclusion, the subject loses certainty in the outside world, but becomes certain only of an existing or potential limitation of their rights. This opens a window for political action. Protests against the restriction of fundamental rights in connection with the imposition of measures and states of emergency in a number of European states are an example of this.

\section{Anti-COVID Protests as Law-Preserving Violence}

Until recently, the vaccination policy implemented by the Russian authorities did not meet with active resistance from some groups of the population, but the issue of introducing mandatory QR codes in public places remained only a matter of time. It was this event that created a rift on a legal basis. The official fact of restricting rights informed people that they were subjects of law, which before, for various reasons, they might not have realized. Awareness of oneself as a subject of law made it possible to defend the law. There are protests emerging in Russia against the introduction of QR codes (Malysheva, 2021) that have not yet reached the level of European demonstrations. However, they have similarities at their base that provide an opportunity for their reflection through a 
common theoretical framework. Of course, the protests vary from country to country. Most researchers tend to think that anti-quarantine protests have a lot of support from right-wing and authoritarian groups (Seiler, 2021; Opratko et al., 2021). I will not examine the demonstrations from the perspective of the political-ideological views of their participants, but I will try to show that, in their essence, these anti-quarantine protests aim to protect the legal order as an ideological structure as they prevent attacks on the rights that underpin it. This does not give us a basis for analyzing their mass or regularity, but allows us to identify the cause of their occurrence.

What rights do the demonstrators stand for? They could be called general liberty rights. The kind of rights that, as Schmitt notes, stand above every organizational and substantive law regulations (2004a: 57). These rights are the freedom of movement, and the freedom of speech of someone who speaks of freedom of body control in relation to a vaccination. However, having originated in the socio-legal order and having been given legislative expression as a result of divine law-making revolutionary violence, these rights are firmly embedded in the legal order. It is true that the socio-legal order moves the rules like pieces on a game-board (Schmitt, 2004b: 57), but it does so on a juridical board. If real law is constituted as a unity between the socio-legal order and the legal order (Antonov, 2013: 171), these rights can be enforced in the modern state as long as the belief that the decision of the parliamentary majority coincides with the will of the people is maintained (Schmitt, 2004a: 24).

The paradox here is that in asserting their fundamental rights, the demonstrators are acting with the same logic as the state. While the preventive counter-COVID-state exercises rather law-extending violence in order to expand opportunities of legal order and maintain order and security through the police and restrictive measures, the protesters are advocating the maintenance of the order of their fundamental rights. However, they cannot conceive of these rights without their guarantee by the state, and therefore also exercise law-preserving violence.

Why, then, are demonstrations forbidden and protesters met with such fierce resistance from the police, if we are not proceeding only from the logic of preserving life? ${ }^{3}$ The answer, in my view, is that the state is simply unable to define legitimate forms of violence accurately because it is de facto forced to recognize the subversive violence it opposes (Honneth, 2009: 114). The state simply cannot distinguish the divine violence that is capable of destroying the existing order, and therefore has to resist any violence that does not come from those who are authorized to do so. Even in the face of the lawpreserving violence of demonstrators who, as we have seen, are not at all for the destruction of the existing order but precisely for the preservation of what is already there, the state continues to assert its monopoly. This, however, leads to a weakening of the original law-making violence, and hence of the foundations of the legal order that has forgotten that it itself is the result of such violence (McLaverty-Robinson, 2013).

3. The exceptions are those countries where demonstrations are more or less peaceful. In these countries, the distinction can be discerned. 
The boundary between the original divine law-making violence and the mythical violence is precarious, and the transition from one to the other, as Žižek shows, quoting Danton, is imperceptible (2008: 201). For this reason, the weakening of the existing legal order hastens its collapse, bringing the coming of the new order closer. The action of suppressing protesters is comparable to that of a masochist. The masochist's torment is the expression of a demand for excessive and unfulfilling love. The masochist does not just demand, but forces love upon themselves. The greater their anxiety, the more they force their partners to love them (Reich, 1980: 244-245). The brutal violent methods of the police are exactly this compulsion to love the established order, asking "We have given you security, why do you refuse to love us?" With each law-extending practice, the demands for love grow stronger, for acts of defiance are in direct correlation with the masochist's anxiety and displeasure.

However, the order itself is an object of desire because social and political interaction takes place within it. However, it is impossible to get out of this perverse relationship with the masochistic order until the fact of the necessity of faith is realized. It was clear to Robespierre that without faith, there can be no true revolution (Žižek, 2008: 202-203), and thus there can be no divine violence that breaks the perverse relationship. If the transition from divine violence to mythological violence is elusive, then Pascal's arbitrariness in the basis of law must be understood as an arbitrariness which began with 'faith in an idea'. This 'faith in something', though, after a successful act of pure violence, is replaced by the pragmatics of a mythical (police) violence of a law-making and law-preserving nature. The "faith in something" gives way to a goal, but it does not disappear completely, only shifting into the realm of the unconscious, or an ideological structuring of the symbolic order. Thus, "faith in something" other than the operative order lies outside the law and, at the same time, is at its foundation. Forgetting this, therefore, law-preserving and law-extending violence brings the destruction of the order closer because its original illegality is revealed. As Pascal wrote, "We must not see the fact of usurpation; law was once introduced without reason, and has become reasonable. We must make it regarded as authoritative, eternal, and conceal its origin, if we do not wish that it should soon come to an end" (1910: 105).

The problem with the forceful suppression of anti-quarantine rallies is that by making opponents of COVID-restrictions the enemy, the legal order labels the inoculated and rule-compliant as its allies. Herein lies the thin thread that links the legal practice of restrictions and legislative innovations to law-extending violence. By recognizing the need for vaccination, one group of people thereby legitimizes the actions of the state to increase restrictions and penalties for COVID-dissidents. One can disagree with the methods used to achieve the goal, but as long as the threat is legally enshrined, these critical voices will be drowned out by volleys of the struggle for public safety. 


\section{Conclusion: Some Reflections on the Politics of the Pandemic}

Peter Wagner expressed the idea that lockdown was a surprise that returned the social imagination and created a temporary world with utopias and dystopias (2020). Utopias are defined as those states that provided broad social support, and dystopias are those countries where authoritarian governments used the situation to consolidate their power. So far, it is difficult to say where Russia stands. Certainly, the tightening of criminal and temporary anti-COVID legislation suggests that we are closer to the second scenario. However, this may, for the moment, be justified by objective necessity or by a specific situation. The fear is that the lack of clearly-defined legal criteria for defining such a situation can lead to the artificial creation of such conditions by a normative system where legal qualification would precede the event. This is not a false consciousness on the lawenforcer, but an essential feature of the law.

The limits of this process can only be seen in the future; in a pandemic, the expansion to which the legal order aspires at the same time as its preservation will be increasingly confronted by conservative forces (not in the sense of political ideology) that seek to preserve the legal order in its status quo. Regardless of the political-ideological views of the protesters, any protest against the violation of rights has its origins in the existing legal order, and has, as its effect, the fundamentals of that legal order. By moving away from the 'faith' that underpins it, the legal order is bringing its disintegration closer.

Despite the seeming impossibility of implementing politics in such circumstances, COVID-19 brought back the possibility of the political, but in its most negative form. Politics in the sense of distinguishing between friend and enemy (Schmitt, 2007: 26) returns through restrictive measures and the introduction of new criminal offenses. The inherent contradiction of a law that enhances the security of some and threatens to incriminate others (McLaverty-Robinson, 2013) is seen in measures to counteract coronavirus infection in the most intense form. Sustainable concepts such as 'quarantine' and 'quarantine measures' are introduced in relation to sick persons and persons who have violated public health legislation (Umnova-Konyukhova, Kostyleva: 115). The community of protected includes those who are vaccinated, and excludes those who may infringe on their well-being.

A process of exclusion and inclusion takes place in society in relation to the vaccinated/unvaccinated, those who believe in the COVID threat and those who do not, and those who agree with measures to eliminate it and those who do not. However, from a temporal perspective, these oppositions of Friend and Enemy, depending on your camp, are false. It is not a civil war that gives the very possibility of politics (Agamben, 2015: 22).

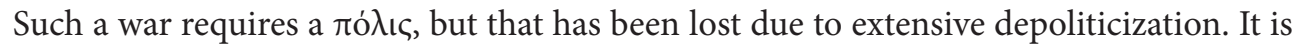
a war to destroy the Other as a phenomenon. The Other, however, does not necessarily have to be human. In fact, COVID could become this non-human Other. A shared sentiment in the face of a non-human threat could generate community (Weibel, 2005: 47), and the exclusion of the virus could sharpen the tensions between the state and society that have been building up over the years. 
Although the pandemic situation is extraordinary, it has not led to extraordinary politics in the sense that Kalyvas understands it (2008: 6). In fact, all of its attempts were stopped. The high level of collective mobilization (demonstrations) as well as the widespread popular support for fundamental change (elections) have been dispersed and stolen. In this context, the UN Secretary General's call for a renewal of both the social and global contract (Guterres, 2020) sounds problematic. There is no telling when we will be able to leave the permanent state of high emergency preparedness which now seems to have become a new normal, not only nationally but also internationally. In order to leave this state, we must learn to distinguish between the boundaries of reality, law, and exception. Then, perhaps, the world can move closer to a new contract. Only one question remains: will it mark the establishment of a new legal order or a prolongation of the old one?

\section{References}

Agamben G. (1998) Homo Sacer: Sovereign Power and Bare Life, Stanford: Stanford University Press.

Agamben G. (2015) Stasis: Civil War as a Political Paradigm, Stanford: Stanford University Press.

Agamben G. (2020) Linvenzione di un'epidemia. Available at: https://www.quodlibet.it/ giorgio-agamben-l-invenzione-di-un-epidemia (accessed 15 September 2021).

Antonov M. (2013) Ojgen Jerlih: zhivoe pravo protiv pravovogo pljuralizma? [Eugen Ehrlich: Living Law versus Legal Pluralism?]. Pravovedenie, no 1, pp. 157-181.

Benjamin W. (1996a) On Language as Such and on the Language of Man. Selected Writings, Vol. 1: 1913-1926 (eds. M. Jennings, M. Bullock), Cambridge: Belknap Press, pp. 62-74.

Benjamin W. (1996b) Critique of Violence. Selected Writings, Vol. 1: 1913-1926 (eds. M. sJennings, M. Bullock), Cambridge: Belknap Press, pp. 236-252.

Cormacain R., Bar-Siman-Tov I. (eds.) (2020) Global Legislative Responses to Coronavirus. The Theory and Practice of Legislation, vol. 8, no 3.

Filippov A. (2020) The Pandemic: First Social Aftereffects and Prospects. Russia in Global Affairs, vol. 18, no 2, pp. 33-40.

Gauchet M. (2020) “C’est un réveil du politique". Available at: https://www.philomag.com/ articles/marcel-gauchet-cest-un-reveil-du-politique (accessed 20 September 2021).

Gephart W. (ed.) (2020) In the Realm of Corona Normativities: A Momentary Snapshot of a Dynamic Discourse, Frankfurt am Main: Vittorio Klosterman.

Greene A. (2020) Derogating from the European Convention on Human Rights in Response to the Coronavirus Pandemic: If Not Now, When? European Human Rights Law Review. Available at: https://papers.ssrn.com/sol3/papers.cfm?abstract_id=3593358 (accessed 20 September 2021).

Gusterson H. (2016) Drone: Remote Control Warfare, Cambridge: MIT Press. 
Guterres A. (2020) Tackling Inequality: A New Social Contract for a New Era. Available at: https://www.un.org/en/coronavirus/tackling-inequality-new-social-contractnew-era (accessed 20 September 2021).

Hart H. L. A. (1994) The Concept of Law, Oxford: Oxford University Press.

Honneth A. (2009) Pathologies of Reason: On the Legacy of Critical Theory, New York: Columbia University Press.

Interlandi J. (2021) The World is at War with COVID. COVID is Winning. Available at: https://www.nytimes.com/2021/o9/21/opinion/sunday/COVID-vaccine-world.html (accessed 20 September 2021).

Kalyvas A. (2008) Democracy and the Politics of the Extraordinary: Max Weber, Carl Schmitt, Hannah Arendt, Cambridge: Cambridge University Press.

Kelsen H. (2008) Reine Rechtslehre: Einleitung in die rechtswissenschaftliche Problematik, Tübingen: Mohr Siebeck.

Khramova T. (2020) Ispytanie pandemiey: ogranicheniya svobody sobraniy I slova v svete printsipa proportsional'nosti [The Challenges of the Pandemic: Restrictions of Freedoms of Assembly and Speech in the Light of the Proportionality Principle]. Comparative Constitutional Review, vol. 29, no 4, pp. 36-54.

Kostyuchenko E., Kozyrev Y. (2020) Noch', den', noch'. Jetot tekst vy prochtete do konca i nakonec nadenete maski [Night, Day, Night: You will Read This Text to the End and Finally Put On Your Masks]. Available at: https://novayagazeta.ru/ articles/2020/11/08/87875-noch-den-noch (accessed 20 September 2021).

Malysheva I. (2021) “Dlja bor'by s pandemiej est' pyl'ca sosny”. V Ekaterinburge sotni chelovek vyshli na akciju protesta protiv QR-kodov. Chto oni govorili ["There's pine pollen to fight the pandemic": Hundreds of People Came Out to Protest against QR Codes in Ekaterinburg. What They were Saying]. Available at: https://www.znak. com/2021-11-13/v_ekaterinburge_sotni_chelovek_vyshli_na_akciyu_protesta_protiv_qr_kodov_chto_oni_govorili (accessed 10 October 2021).

McLaverty-Robinson A. (2013) Benjamin: Critique of the State. Available at: https:// ceasefiremagazine.co.uk/walter-benjamin-critique-state/ (accessed 1o October 2021).

Merkulenko A. (2021) Chrezvychaynye polnomochiya organov vlasti sub'ektov federatsii (shtatov) v Rossii, SShA i Brazilii v usloviyakh rasprostraneniya novoy koronavirusnoy infektsii [Emergency Powers of the Authorities of the Constituent Units of the Federation (States) in Russia, the USA and Brazil amid the Spread of a New Coronavirus Infection]. Comparative Constitutional Review, vol. 30, no 3, pp. 86-107.

Nasulina J. (2021) V Volgograde neizvestnye vorvalis' v zdanie Rospotrebnadzora [Unknown Assailants Break into Rospotrebnadzor Building in Volgograd]. Available at: https://ria.ru/20211119/volgograd-1759814786.html (accessed 7 December 2021).

Novaya gazeta (2021) Desjatki zhitelej Cheljabinska popytalis' prorvat'sja na zasedanie Zaksobranija, gde prinimali zakonoproekt o QR-kodah [Dozens of Chelyabinsk Residents Tried to Break Through to the Session of the Regional Legislative Assembly where the Legislation on QR Codes was Passing]. Available at: https://novayagazeta. $\mathrm{ru} /$ articles/2021/11/25/desiatki-zhitelei-cheliabinska-popytalis-prorvatsia-na-zase- 
danie-zaksobraniia-gde-prinimali-zakonoproekt-o-qr-kodakh-news (accessed 7 December 2021).

Opratko, B., Bojadžijev M., Bojanić S. M., Fiket I., Jonsson S., Harder A., Nećak M., Neegard A., Ortega Soto C., Pudar Draško G., Sauer B., Stojanović Čehajić K. (2021) Cultures of Rejection in the COVID-19 Crisis. Ethnic and Racial Studies, vol. 44, no 5, pp. 893-905.

Panzeri F., Di Paola S., Domaneschi F. (2021) Does the COVID-19 War Metaphor Influence Reasoning? PLoS, vol. 16, no 4. Available at: https://journals.plos.org/plosone/ article?id=10.1371/journal.pone.0250651 (accessed 15 September 2021).

Pascal B. (1910) Thoughts, Letters, and Minor Works, New York: P. F. Collier.

Platon S. (2020) From One State of Emergency to Another - Emergency Powers in France. Available at: https://verfassungsblog.de/from-one-state-of-emergency-toanother-emergency-powers-in-france/ (accessed 15 September 2021).

Reich W. (1980) Character Analysis, New York: Farrar, Straus \& Giroux.

Roach K. (2004) Anti-Terrorism and Militant Democracy: Some Western and Eastern Responses. Militant Democracy (ed. A. Sajo), Amsterdam: Eleven International Publishing, pp. 171-207.

Sajó A., Uitz R. (2017) The Constitution of Freedom: An Introduction to Legal Constitutionalism, Oxford: Oxford University Press.

Schmitt C. (2004a) Legality and Legitimacy, Durham: Duke University Press.

Schmitt C. (2004b) On the Three Types of Juristic Thought, Westport: Praeger.

Schmitt C. (2007) The Concept of the Political, Chicago: University of Chicago Press.

Seiler M. (2021) From Anti-mask to Anti-state: Anti-lockdown Protests, Conspiracy Thinking and the Risk of Radicalization. Available at: https://kingsthinktank. com/2021/05/10/from-anti-mask-to-anti-state-anti-lockdown-protests-conspiracythinking-and-the-risk-of-radicalization/ (accessed 1o October 2021).

Seyhan E. (2020) Pandemic Powers: Why Human Rights Organizations Should Not Lose Focus on Civil and Political Rights. Journal of Human Rights Practice, vol. 1, no 8, pp. 268-275.

Startceva O. (2020) The Right to a Fair Trial in the Context of COVID-19 in Russia. Available at: https://legal-dialogue.org/the-right-to-a-fair-trial-in-the-context-of-COVID19-in-russia (accessed 15 September 2021).

Tzevelekos V. (2020) Herd Immunity and Lockdown: The Legitimacy of National Policies Against the Pandemic and Judicial Self-Restraint by the ECtHR. Available at: https:// strasbourgobservers.com/2020/05/11/herd-immunity-and-lockdown-the-legitimacyof-national-policies-against-the-pandemic-and-judicial-self-restraint-by-the-ecthr/ (accessed 15 September 2021).

Umnova-Konyukhova I., Kostyleva E. (2021) Konstitucionnye ogranichenija prav i svobod: sravnitel'no-pravovoe issledovanie reshenij Konstitucionnogo Suda Rossijskoj Federacii, Verhovnogo Suda Rossijskoj Federacii i ESPCh [Constitutional Limitations on Rights and Freedoms: A Comparative Legal Study of Decisions of The Russian Constitutional Court, the Supreme Court of the Russian Federation and the ECtHR], Moscow: RGUP. 
UN Experts (2020) COVID-19: States Should not Abuse Emergency Measures to Suppress Human Rights. Available at: https://www.ohchr.org/en/NewsEvents/Pages/DisplayNews.aspx?NewsID=25722\&LangID=E (accessed 15 September 2021).

Varlamova N. (2020) Pandemiya COVID-19 kak vyzov konstitutsionnomu pravoporyad$\mathrm{ku}$ [COVID-19 Pandemic as a Challenge to Constitutional Legal Order]. Comparative Constitutional Review, vol. 29, no 6, pp. 17-30.

Wagner P. (2020) COVID-19, HIV/AIDS, and the "Spanish Flu": Historical Moments and Social Transformations. Thesis Eleven. Available at: https://thesiseleven. com/2020/o7/24/COVID-19-hiv-aids-and-the-spanish-flu-historical-moments-andsocial-transformations/ (accessed 15 October 2021).

Weibel P. (2005) Theorien zur Gewalt: Benjamin, Freud, Schmitt, Derrida, Adorno. Theologie und Politik: Walter Benjamin und Paradigma der Moderne (eds. B. Witte, P. Mauro), Berlin: Erich Schmidt, pp. 44-57.

Žižek S. (2008) Violence: Six Sideways Reflections, New York: Picador.

\section{Расширение правопорядка в период пандемии: российская перспектива}

\section{Марк Белов}

Стажер-исследователь, Центр фундаментальной социологии, Национальный исследовательский университет «Высшая школа экономики»

Студент бакалавриата, юридический факультет, Национальный исследовательский университет «Высшая школа экономики» в Санкт-Петербурге

Адрес: ул. Мясницкая, д. 20, г. Москва, Российская Федерация 101000

E-mail: markusabelov@gmail.com

Беспрецедентные меры карантинного регулирования заставили философов и юристов всего мира говорить о хрупкости демократических свобод и возвращении чрезвычайного положения как политической реальности, описанной в трудах теоретиков XX века.

Однако введенные ограничения рассматриваются в этих работах либо в связи с правовым механизмом их введения, либо через призму политической философии. Кроме того, российский опыт не получил достаточного освещения в публикациях. В данной статье предпринята попытка синтеза правового анализа с политико-правовой философией с целью показать, что расширение правового порядка всегда заложено в его логике. В первой части статьи на примере материально-правовой практики показывается, как то, о чем говорилось на уровне философской рефлексии и применительно к зарубежным правовым порядкам, было реализовано в России. Во второй половине текста обращается внимание на логику протеста, которая совпадает с логикой как полиции, так и государства. Поскольку права, на которые обращают внимание протестующие, имеют своим источником именно существующий правовой порядок, то и действия правоохранительных органов, и действия протестующих направлены на его защиту. Опасность такой ситуации заключается в том, что нормативная система в будущем может потенциально заменить социальную реальность.

Ключевые слова: чрезвычайное положение, насилие, право, правопорядок, Вальтер Беньямин, пандемия 